\title{
Selective Hydrogenation of 1,3-Butadiene over Supported Nickel Catalyst Obtained from Nickel-Zirconia Solid Solution
}

\author{
Jong-San Chang, ${ }^{*}$ Jae Oak Ryu, Jong Min Lee, Sang-Eon Park ${ }^{\phi, \star}$ Do-Young Hong, and Sung Hwa Jhung \\ Research Center for Nanocatalysts, Korea Research Institute of Chemical Technology (KRICT), Yuseong, \\ Daejeon 305-600, Korea. "E-mail:jschang@krict.re.kr. \\ ${ }^{\dagger}$ Department of Chemistry, Inha University, Incheon 402-751, Korea. E-mail. separk@inha.ackr.
}

Received May 6, 2005

\begin{abstract}
Catalytic properties of $\mathrm{Ni}-\mathrm{ZrO}_{2}$ catalysts prepared by coprecipitation have been studied for the gas-phase

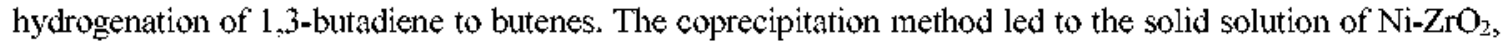
which contains highly resistant $\mathrm{Ni}$ species to thermal reduction with $\mathrm{H}_{2}$. Nickel species of the solid solution were highly dispersed in the $\mathrm{ZrO}_{2}$ lattice, so that the reduced catalysts were selective for hydrogenation of 1,3butadiene to butenes $(99.9 \%)$ even in the presence of 1-butene.
\end{abstract}

Key Words : $\mathrm{Ni}_{-} \mathrm{ZrO}_{2}$, Solid solution, Selective hydrogenation

\section{Introduction}

Zirconia and its solid solutions are interesting materials of current technological and scientific fields.' In particular, they find applications as catalyst, support or electrode in environmental catalysis, high temperature fuel cell and electrochemical cells. In recent years, much work has been devoted to study chemically or physically modified $\mathrm{ZrO}_{2}$ as a new generation catalyst. ${ }^{2-5}$ Its superiority in catalytic application has been ascribed to the following two properties: (i) $\mathrm{ZrO}_{2}$ gives rise to a unique interaction between the active catalytic phase and support and (ii) it is chemically more inert than classical support materials such as $\mathrm{Al}_{2} \mathrm{O}_{3}$, $\mathrm{MgO}$, and $\mathrm{SiO}_{2}$. Pure zirconia exists in a monoclinic phase at room temperature. Nevertheless, tetragonal and cubic phases can be formed at room temperature by adding adequate amounts of oxides of metals with similar radii to that of $\mathrm{Zr}$. Numerous investigations on the phase stabilization process of $\mathrm{ZrO}_{2}$ by doping alkali and rare-earth metal oxides have been carried out for several decades. ${ }^{6}$ Moreover, the catalytically active components, such as transition metals and noble metals, can be incorporated into $\mathrm{ZrO}_{2}$ matrix through several preparation methods. ${ }^{7}$ The binary $\mathrm{Ni}-\mathrm{ZrO}_{2}$ system has the ability to form metastable solid solutions since the presence of nickel favors the formation of metastable tetragonal zirconia. ${ }^{8}$ The state of nickel in the $\mathrm{Ni}_{-} \mathrm{ZrO}_{2}$ system strongly depends on the preparation procedure. However, catalytic properties of the $\mathrm{Ni}-\mathrm{ZrO}_{2}$ solid solutions have not been studied in detail until now. This work concerns preparation of the $\mathrm{Ni}-\mathrm{ZrO}_{2}$ solid solution and its catalytic properties especially for hydrogenation reaction.

The versatility of catalytic hydrogenation allows the selective conversions of functionalized hydrocarbons. ${ }^{9}$ Selective hydrogenation of diolefin to the corresponding monoolefin over supported Pd catalysts plays an important role in producing high purity alkene streams on an industrial scale. ${ }^{10}$ In fact, modern industrial processes use the selective hydrogenation for the purification of petrochemical products generated from cracking units by removing acetylene and 1,3-butadiene in the ethylene-rich cut and butene-rich cut, respectively. A number of studies have been devoted to the selective hydrogenation of 1,3-butadiene to butene since the 1960s." Although palladium is the most useful catalyst for the partial hydrogenation reactions of alkynes and dienes due to its outstanding intrinsic selectivity, the development of nickel-based catalysts for such reactions is highly promising due to the high cost and limited availability of noble metals. However, the application of nickel catalysts to the selective hydrogenation has been very rare due to low selectivity in general. In this work, we suggest the $\mathrm{ZrO}_{2}-$ supported nickel catalyst induced from $\mathrm{Ni}-\mathrm{ZrO}_{2}$ solid solution as a selective hydrogenation catalyst, especially, in partial hydrogenation reactions. The selective hydrogenation of 1,3-butadiene to butenes was investigated as a test reaction to evaluate catalytic activity and selectivity of reduced nickel species in the $\mathrm{Ni}-\mathrm{ZrO}_{2}$ system.

\section{Results and Discussion}

It has been reported that the tetragonal phase can be obtained by the addition of foreign metal species with a suitable preparation method since the presence of foreign species plays an important role to derive the zirconia structure. ${ }^{12}$ Likewise, for $\mathrm{Ni}_{-} \mathrm{ZrO}_{2}$ system a chemical precipitation method leads to the formation of a metastable tetragonal $\mathrm{ZrO}_{2}$. Using the precipitation method the tetragonal phase $\mathrm{ZrO}_{2}$ in the $\mathrm{NiO}-\mathrm{ZrO}_{2}$ system is dominantly obtained in the range of $1-7 \mathrm{wt} \% \mathrm{NiO}$ loading. Figure 1 illustrates the XRD patterns for the $1 \mathrm{wt} \%$ and $3 \mathrm{wt} \% \mathrm{Ni}-$ doped $\mathrm{ZrO}_{2}$ catalysts, which clearly indicate the formation of a dominant tetragonal phase in the $\mathrm{ZrO}_{2}$ matrix. It is noted that no crystalline peaks related to $\mathrm{NiO}$ in XRD pattems were detected up to $7 \mathrm{wt} \% \mathrm{NiO}$ loading. This means that $\mathrm{NiO}$ in the $\mathrm{NiO}-\mathrm{ZrO}_{2}$ is highly dispersed in a zirconia matrix or exists as an amorphous state. In the tetragonal zirconia, 


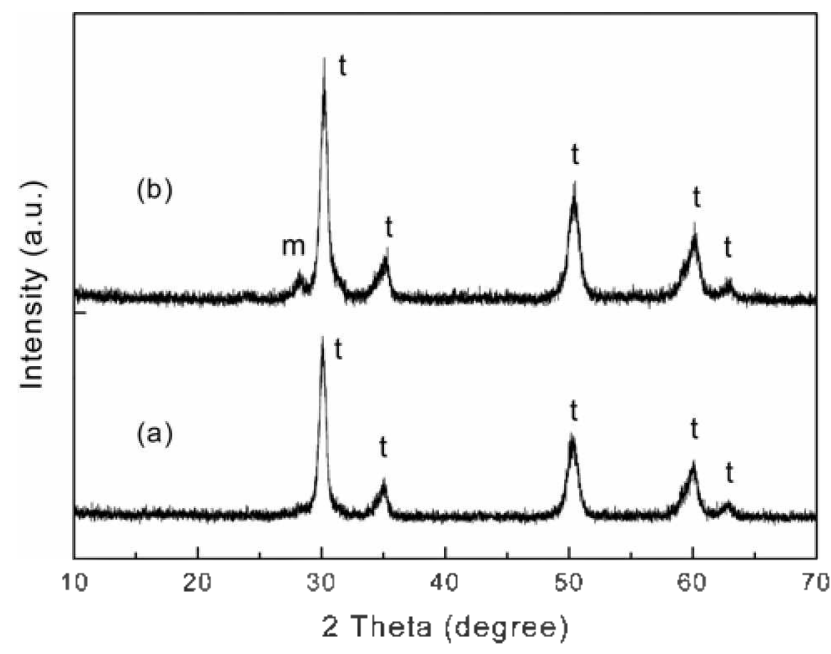

Figure 1. XRD patterns of (a) $1 \mathrm{wt} \%$ and (b) $3 \mathrm{wt} \% \mathrm{Ni}-\mathrm{ZrO}$ catalysts. Notation: $t$, tetragonal $\mathrm{ZrO}_{2} ; \mathrm{m}$, monoclinic $\mathrm{ZrO}_{2}$.

nickel species can be incorporated in the zirconia structure so that they form the solid solution with the zirconia framework. As mentioned above, the tetragonal $\mathrm{Ni}-\mathrm{ZrO}_{2}$ phase is formed even at room temperature by adding nickel cations to have similar radius to that of $\mathrm{Zr}^{4+}\left(0.69 \AA\right.$ for $\mathrm{Ni}^{2-}$ w. $0.72 \AA$ for $\mathrm{Zr}^{++}$). The incorporation of $\mathrm{Ni}$ into zirconia lattice to form solid solution was also confirmed by EXAFS analysis. ${ }^{13}$ For $\mathrm{Ni}$ K-edge EXAFS of $\mathrm{NiO}-\mathrm{ZrO}_{2}$, the spectrum displayed the first coordination shell of $\mathrm{Ni}-\mathrm{O}$ with octahedral environment while there was a trace of the second-neighboring nickel atoms, indicating that nickel cations are almost atomically dispersed in the framework. XPS analysis of $\mathrm{Ni}-\mathrm{ZrO}_{2}$ revealed higher binding energy $\left(855.7 \mathrm{eV}\right.$ ) in Ni $2 \mathrm{p}_{3 / 2}$ core level as compared to that of bulk $\mathrm{NiO}(854.0 \mathrm{eV})$, indicating strong interaction between nickel and zirconia matrix. In addition, the concentration of the surface $\mathrm{Ni}^{2+}$ ions determined by the ratio of photoelectron peak area of $\mathrm{Ni} 2 \mathrm{p}_{3 / 2}$ to that of $\mathrm{Zr} 3 \mathrm{~d}\left(\mathrm{R}_{\mathrm{Ni} / \mathrm{r}}\right)$ showed $\mathrm{Ni}^{2+}$ surface content in tetragonal $\mathrm{ZrO}_{2}$ was much lower than bulk $\mathrm{Ni}$ content. These supplementary results suggest that nickel species of the solid solution are highly dispersed in the lattice of tetragonal zirconia. Until some threshold concentration, the solid solution of $\mathrm{Ni}-\mathrm{ZrO}_{2}$ prevents the aggregation of nickel oxide on the zirconia surface because nicke] in a dispersed state of nickel oxide enters the solid solution of zirconia lattice.

TPR experiment has been carried out to determine the reducibility of $\mathrm{Ni}$ and interaction between nickel and support. As shown in Figure 2, $\mathrm{Ni}-\mathrm{ZrO}_{2}$ catalysts show reduction peaks at temperature higher than $400^{\circ} \mathrm{C}$ and the reduction peaks shift to higher temperature at lower $\mathrm{Ni}$ loading. Considering reduction temperature $\left(250-350{ }^{\circ} \mathrm{C}\right)$ of bulk $\mathrm{NiO}$, these peaks at higher temperatures are ascribed to much strong interaction of nickel oxide and tetragonal zirconia. TPR profiles of these catalysts verify that the reduction of $\mathrm{Ni}^{2+}$ or $\mathrm{NiO}$ in the solid solution is strongly hindered.

Table 1 summarizes catalytic activities and selectivities of $1 \%$ and $3 \% \mathrm{Ni}-\mathrm{ZrO}_{2}$ catalysts reduced at $400^{\circ} \mathrm{C}$ for $1 \mathrm{~h}$ in

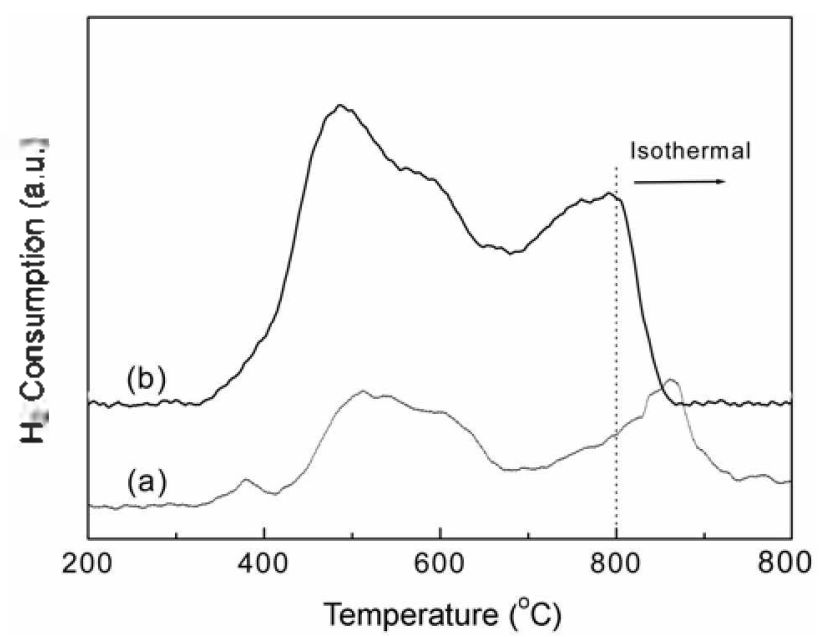

Figure 2. TPR profiles of (a) $1 \mathrm{wt} \%$ and (b) $3 \mathrm{wt} \% \mathrm{Ni}-\mathrm{ZrO}=$ catalysts. Ramping rate: $10^{\circ} \mathrm{C} / \mathrm{min}$.

Table 1. Selective hydrogenation of 1,3-butadiene over $\mathrm{Ni}-\mathrm{ZrO}_{2}$ catalysts

\begin{tabular}{|c|c|c|c|c|c|c|}
\hline \multirow{2}{*}{$\begin{array}{c}\mathrm{Ni} \\
\text { loading } \\
(\mathrm{wt} \%)\end{array}$} & \multirow{2}{*}{$\begin{array}{c}\text { BD } \\
\text { Conv. } \\
(\%)\end{array}$} & \multirow{2}{*}{$\begin{array}{c}\text { Suutenes } \\
(\%)\end{array}$} & \multicolumn{4}{|c|}{ Selectivity $(\%)$} \\
\hline & & & $\mathrm{n}-\mathrm{C}_{+} \mathrm{H}_{10}$ & $1-\mathrm{C}_{4} \mathrm{H}_{8}$ & $\mathrm{c}-2-\mathrm{C}_{4} \mathrm{H}_{8}$ & $-2-\mathrm{C}_{4} \mathrm{H}_{8}$ \\
\hline 1.0 & 5.4 & 96.3 & 3.7 & 35.2 & 20.4 & 40.7 \\
\hline 3.0 & 70.9 & 99.7 & 0.3 & 40.4 & 16.4 & 42.9 \\
\hline $3.0^{*}$ & 51.7 & 99.9 & 0.1 & 50.4 & 13.2 & 36.3 \\
\hline
\end{tabular}

Reaction conditions: Temp. $=100^{\circ} \mathrm{C}, \mathrm{W} / \mathrm{F}=0.6 \mathrm{~g} \cdot \mathrm{min} / \mathrm{mL}, \mathrm{H}_{2} \mathrm{BD}=2$ (molar ratio), $\mathrm{P}$ (BD) $=10.1 \mathrm{kPa}$. Time on stream: $1 \mathrm{~h}$. Notation: BD, 1,3butadiene. ${ }^{*}$ Competitive hydrogenation of 1,3-butadiene in the presence of 1-butene: Temp. $=100^{\circ} \mathrm{C}$, W/F $=0.6 \mathrm{~g} \cdot \mathrm{min} / \mathrm{mL}, \mathrm{P}$ (olefins) $=15.1 \mathrm{kPa}$, $\mathrm{H} / \mathrm{BD}=1.5$ (molar ratio), $\mathrm{BD} / 1$-bulene $=0.312$ (molar ratio).

the selective hydrogenation of 1,3-butadiene. Although 1 $\mathrm{wt} \% \mathrm{Ni}-\mathrm{ZrO} 2$ exhibits very poor activity for hydrogenation, $3 \mathrm{wt} \% \mathrm{Ni}-\mathrm{ZrO}$, shows very high selectivity $(99.7 \%)$ to butenes with moderate activity. It seems that the $\mathrm{Ni}$ content of more than $1 \mathrm{wt} \%$ is necessary for obtaining reasonable activity over the catalysts induced from the $\mathrm{Ni}-\mathrm{ZrO}_{2}$ solid solution.

For supported Pd catalysts high trans/cis ratios (4-12) of the 2-butenes in the products have been generally observed. ${ }^{11}$ On the other hand, the reduced $\mathrm{Ni}-\mathrm{ZrO}_{2}$ catalysts give much lower trans/cis ratios $(2.0-2.6)$, close to the equilibrium ratio. This suggests that an adsorption mode of the partially hydrogenated intermediate is different from that on $\mathrm{Pd}$ catalyst, which is assumed to be a $\pi$-allyl species. Butenes produced by the hydrogenation may either undergo desorption or subsequent hydrogenation. In general, 1,3butadiene is more strongly adsorbed on group VIII metals than butenes formed by hydrogenation. The desorption rate of butenes on catalyst surface that is mainly determined by the relative difference in the adsorption strength of $1,3-$ butandiene and butenes depends markedly on the surface structure of the active nickel sites. The high butenes selectivity on the reduced $\mathrm{Ni}-\mathrm{ZrO}_{2}$ may be due to the high desorption rate of butene internediates.

In addition to high perfonnance toward selective hydro- 


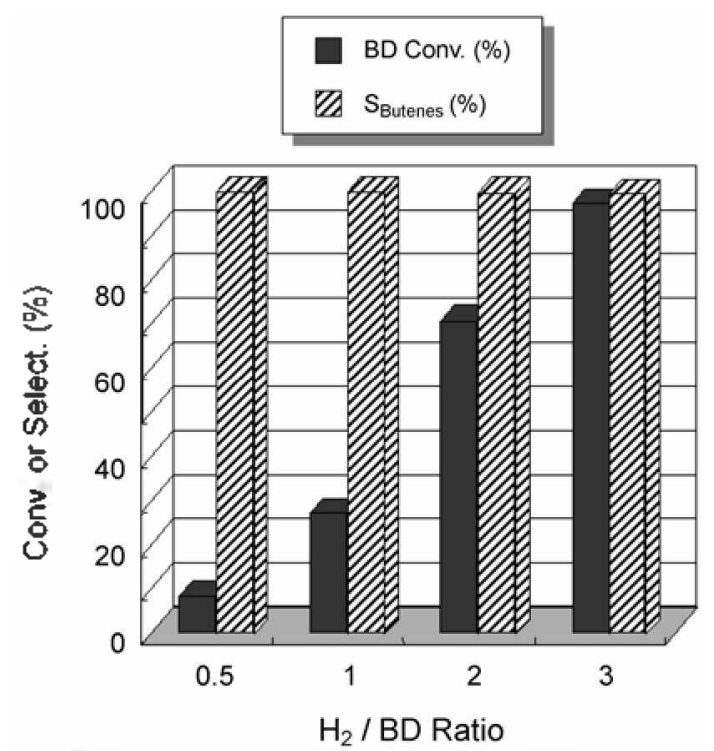

Figure 3. Effect of $\mathrm{H}_{2} / \mathrm{BD}$ ratio on catalytic activity and selectivity. Catalyst: $3 \mathrm{wt} \% \mathrm{Ni}-\mathrm{ZrO}_{2}$. Reaction conditions: see Table 1.

genation, another characteristic of the $\mathrm{Ni}-\mathrm{ZrO}_{2}$ catalyst is insensitivity of its selectivity to hydrogen concentration, as illustrated in Figure 3. Its selectivity to partial hydrogenation is not changed significantly even when the ratio of hydrogen to butadiene increases from 0.5 to 3 , as contrasted to the general behavior of hydrogenation catalysts that tends to lose their selectivities easily at higher hydrogen concentration $\left(\mathrm{H}_{2} / \mathrm{BD}>1\right){ }^{9}$ Instead, the hydrogenation activity increases steadily with an increase of hydrogen concentration. It is also observed that the $\mathrm{Nj}-\mathrm{ZrO}_{2}$ catalysts are much selective for hydrogenation of 1,3-butadiene to butenes $(50.4 \%)$ even in the presence of I-butene. The catalytic results clearly suggest that $\mathrm{Ni}$ species incorporated into the zirconia framework are highly selective for partial hydrogenation of diolefins.

In summary, the coprecipitation method led to the solid solution of $\mathrm{Ni}-\mathrm{ZrO}_{2}$ to contain $\mathrm{Ni}$ species highly resistant against themal reduction with $\mathrm{H}_{2}$. Nickel species of the solid solution were highly dispersed in the $\mathrm{ZrO}_{2}$ lattice, which were highly selective for hydrogenation of 1,3butadiene to butenes. This work demonstrates that $\mathrm{ZrO}_{2}$ supported $\mathrm{Ni}$ catalysts derived from the solid solution of $\mathrm{Ni}$ $\mathrm{ZrO}_{2}$ could be utilized for selective hydrogenation.

\section{Experimental Section}

Ni-doped zirconia ( $\mathrm{NiO}-\mathrm{ZrO}_{2}$ ) materials were prepared by chemical precipitation method. Thus, synthesis of these materials with $1-7 \mathrm{wt} \%$ of $\mathrm{NiO}$ loading was carried out by hydrolyzing the solution of $\left.\mathrm{ZrO}_{\left(N_{3}\right.}\right)_{2} \cdot \mathrm{H}_{2} \mathrm{O}$ (Fluka) and $\mathrm{Ni}\left(\mathrm{NO}_{3}\right)_{2} \cdot 6 \mathrm{H}_{2} \mathrm{O}$ (Aldrich) and neutralizing the resultant sol with aqueous ammonia solution $(28 \%)$ to obtain a precipitate $(\mathrm{pH} \sim 9)$ in continuous stirring, followed by aging at 30 $40{ }^{\circ} \mathrm{C}$ for $6 \mathrm{~h}$. The precipitate was washed with distilled water and dried at $100^{\circ} \mathrm{C}$. The as-prepared powder was calcined at $600^{\circ} \mathrm{C}$ for $6 \mathrm{~h}$ in air. The selective hydrogenation of 1,3-butadiene to butenes was carried out with a conventional fixed-bed microreactor made of quartz at atmospheric pressure. Before catalytic measurement, the catalyst was reduced with $5 \% \mathrm{H}_{2} / \mathrm{N}_{2}$ at $400^{\circ} \mathrm{C}$ for $1 \mathrm{~h}$. The reaction was carried out by introducing a mixture of 1,3butadiene (purity: $99.0 \%+$ ) and pure hydrogen in helium balance. The effluent stream from the reactor was analyzed by an on-line gas chromatograph (HP 5890 Series II) equipped with a capillary column ( $\& \mathrm{~W}, \mathrm{GS}-\mathrm{Al}_{2} \mathrm{O}_{3}$ ) and a flame ionization detector.

Acknowledgements. This work was supported by the Korea Ministry of Science and Technology through the Institutional Research Program. The authors thank Dr. I.S. Mulla for useful discussions.

\section{References}

I. Yamaguchi, T. Catal. Todor $1994,20,199$.

2. Park, J. N.; Noh, J. J.; Chang, J.-S.; Park, S.-E. Catal. Lett. 2000, $65,75$.

3. Choi, Y.-S.; Park, Y.-K.; Chang, J.-S.; Park, S.-E.; Cheetham, A. K. Catal. Lett. 2000, 60,93.

4. Li, X.; Chang, J.-S.; Park, S.-E. Chem, Lett. 1999, 1099.

5. Park, J. N.; Lee, C. W.; Park, S.-E.; Chang, J.-S.; Shin, C. H. Bull. Korean Chem. Soc. 2004, 25, 1355.

6. Yashima, M.; Hirosw, T.; Katano, S.; Suzuki, Y.; Kakihana, M.; Yoshimera, M. Phys. Rev. 1995, B51, 8018.

7. Zeng. H. C.; Lin, J.; Teo, W. K.; Loh, F. C.; Tan, K. L. J. NonConstaline Solids 1995, $181,49$.

8. Valigi, M.; Gazzoli, D.; Dragone, R,; Gherardi, M.; Minelli, G. $J$. Mater, Chem, 1995, 5, 183.

9. Amold, H.; Doebert, F.; Gaube, J. In Handbook of Heterogeneous Catahsis; Ent, G., Knoezinger, H., Weitkamp, J., Eds.; VCH: Weinheim, 1997; Vol. 5, pp 2165-2186.

10. Choi, S. H.; Lee, J. S. J. Catal. 2000, $193,176$.

11. Sakany, A.; Schay, Z; Stefler, Gy.; Borko, L.; Hightower, J. W; Guczi, L. Appl. Catal A: General 1995, 124, L181.

12. Afanasiev, P.; Thiollier, A.; Breysse, M.; Dubois, J. L. Topics Catal. 1999, 8, 147 .

13. Chang. J.-S.; Hwang, J.-S.; Hwang, Y. K.; Jhung, S. H. in preparation. 